\title{
The Unity of the Church in the Ecumenical Dialogue between the Roman Catholic Church and the World Council of Churches
}

The unity of the church remains a priority task for all Christians. The Holy Trinity constitutes the inner principle of every ecclesial communion. The relationship between the love of the Father, the Son and the Holy Spirit is a gift and a task for the community of believers. The unity of the church is rooted in the Scriptures. The dialogue board specifically highlights the high priestly prayer of Jesus and the Lord's Prayer as a biblical base for the ecumenical activity of the church. Early Christian koinonia is an example of unity to which divided Christians should strive. Despite the lack of full communion, the Churches and Christian communities today can grow in spiritual unity through prayer and daily life, becoming witnesses of reconciliation and love in a divided world..

Key words: unity, Church, Joint Working Group, Roman Catholic Church, World Council of Churches.

\section{Introduction}

The unity of the church remains a priority task for all Christians, which has its source in the high priestly prayer of Jesus, "may they all be one" (John 17, 21). As a consequence of the Second Vatican Council, the Roman Catholic Church (RCC) officially began collaboration with the World Council of Churches (WCC) in the framework of the Joint Working Group (JWG) in 1965. Until today 9 published reports $(1966 ; 1967 ; 1971 ; 1975 ; 1982 ; 1990 ; 1998 ; 2005 ; 2013)$ and 14 
Theology of dialogue

elaborated study documents („Catholicity and Apostolicity”, 1968; „Common Witness and Proselytism”, 1970; „Common Witness”, 1980; „Hierarchy of Truths”, 1990; „The Church: Local and Universal”, 1990; „Ecumenical Formation”, 1994; „Common Witness and Proselytism”, 1996; „Ecumenical Dialogue on Moral Issues”, 1996; "Ecclesiological and ecumenical implications of a common baptism", 2005; "The nature and purpose of ecumenical dialogue", 2005; "Inspired by the same vision": Roman Catholic participation in national and regional councils of churches, 2005; "Reception: A Key to Ecumenical Progress, 2013; "Be renewed in the Spirit. The Spiritual Roots of Ecumenism", 2013; "The Church in the Life of Youth and Youth in the Life of the Church", 2013) show the fruitful cooperation of both sides in their bilateral dialogue during the last 50 years.

The aim of this study is a synthetic presentation of the idea of the unity of the church that has been achieved and elaborated in the RCC's dialogue with the WCC, held in the framework of the JWG. This issue will be developed in five parts. At the beginning the Trinitarian aspect of ecclesial communion (chapter 1) and its biblical roots (chapter 2) will be shown, going further to the issue of the unity of the church understood as koinonia (chapter 3). Later it is important to focus on how the unity can be realized in the life and worship of the church (chapter 4). Finally, it should be examined whether or not it is possible for the different churches to bear a common witness in the contemporary world (chapter 5). The structure of this study follows the pattern of the JWG method of analysis.

\section{Trinity as the Interior Principle of Ecclesial Communion}

It is impossible to speak about the unity of the church without reference to the Holy Trinity. The JWG emphasizes that "the church is the icon of the Trinity", while at the same time the Trinity constitutes "the interior principle" of the church. ${ }^{1}$ The Trinitarian community of mutual love is a gift to all humanity. ${ }^{2}$ The Father reveals himself

1 Joint Working Group, "The Church: Local and Universal” (study document), 1, in: Joint Working Group between the Roman Catholic Church and the World Council of Churches, Sixth Report, (Geneva-Rome: WCC Publications, 1990), 23-37.

2 Idem, "Catholicity and Apostolicity" (study document), 1, in: Joint Working Group between the Roman Catholic Church and the World Council of Churches, Third Official Report, in: One In Christ 4, 3 (1970), 452-483 and Ecumenical Review 23, 1 (1971), 51-69. 
through his word, Jesus Christ (cf. Heb 1: 1-2; John 1:14), ${ }^{3}$ the Lord, whose "name is above every name" (Phil. 2:9). ${ }^{4}$ Due to the incarnation of the Savior, his announcement of the kingdom, his death and resurrection, "all things are to be reconciled to God" (Col. 1:20). Jesus "gathers all humanity into his Body by the action of the Holy Spirit" (Eph. 1:1-4). ${ }^{5}$ The Son answers to the Father through the Spirit, that is a "communion of life". ${ }^{6}$

According to the JWG, the christological and pneumatological dimension of church unity is visible in the teachings of the Church Fathers: "where Jesus Christ is, there is the Church Catholic"; "where the Church is, there is the Spirit, and where the Spirit is, there is the Church". ${ }^{8}$ St. Cyprian points out the Trinitarian character of the Church: "The Church is a people made one with the unity of the Father, the Son, and the Holy Spirit. ${ }^{9}$

The JWG endorse the Nicene Constantinopolitan Creed (381 C.E.) which teaches that the Father Almighty, the begotten Son and the Holy Spirit who gives life are the one God: distinct in identity but sharing the one divine nature. ${ }^{10}$

In God's plan exists only one church, which is the body of Christ, present due to God's Son and gathered by the action of the Holy Spirit from Pentecost onwards in the local churches all over the world. ${ }^{11}$ The authentic call to the churches is to create a real koinonia with the Triune God and among themselves. This unity is a gift of God, enabled through the activity of the Holy Spirit, bestowing his fruits of "love,

3 Idem, "The Nature and Purpose of Ecumenical Dialogue" (study document), 25, in: Joint Working Group between The Roman Catholic Church and the World Council of Churches, Eighth Report 1999-2005, (Geneva-Rome: WCC Publications, 2005), 73-89.

Idem, Catholicity and Apostolicity, 1. Bible quotations are given in the translation as found in the JWG documents.

5 Ibidem. Idem, The Nature and Purpose of Ecumenical Dialogue, 25. Ignatius of Antioch, To the Smyrnaens, VIII.2 as cited in: JWG, The Church: Local and Universal, 3.

Irenaeus, Adversus Haereses 111.24.1 as cited in: JWG, The Church: Local and Universal, 3.

Cyprian, De Orat. Dom. 23, PL 4:553 as cited in: JWG, The Church: Local and Universal, 1.

JWG, "Be Renewed in the Spirit: the Spiritual Roots of Ecumenism", 37, in: Joint Working Group between the Roman Catholic Church and the World Council of Churches, Ninth Report 2007-2012, (Geneva: WCC Publications, 2013), 103-138. 
joy, peace, patience, kindness, generosity, faithfulness, gentleness, and self-control" (Gal 5:22). ${ }^{12}$

\section{Biblical Foundations of the Unity of the Church}

Theology of dialogue

The JWG between the RCC and the WCC focuses on the high priestly prayer of Jesus as the important principle of theological foundation for the unity of the church: "I ask not only on behalf of these, but also on behalf of those who will believe in me through their word, that they may all be one. As you, Father, are in me and I am in you, may they also be in us, so that the world may believe that you have sent me" (John 17:20-21). In the interpretation of JWG Jesus asks the Father for his disciples, but also for those who will believe in him, for the communion of love among them which he shares with the Father, that is the condition of bearing fruit (cf. John 15:5). Giving one's life for others becomes the highest point of unity which imitates Christ's sacrifice on the cross (cf. John 13:1; 15:13). Jesus is the unique way to the Father (cf. John 8:12; 14:7). First Christians grew in this community of love through remaining in apostolic teaching, the breaking of the bread and sharing the wealth among those who were in need (cf. Acts $2: 42,44-45)$. A prayer that has its roots in the high priestly prayer of Jesus enables Christians to experience their interior conversion and become instruments of healing and witnesses of diverse gifts in the Holy Spirit which creates new opportunities to achieve a true unity. ${ }^{13}$

Another biblical passage that the JWG has chosen as the basis for the unity of the church is the Lord's Prayer, where Christians ask the Father for the heavenly kingdom, which has to be built through forgiveness of sins and mutual reconciliation in Christ. ${ }^{14}$ It is a common prayer for all people of God, because "we say not 'My Father, which art in heaven,' nor 'Give me this day my daily bread'... When we pray [the Lord's Prayer] we pray not for one but for the whole people, because we the whole people are one". ${ }^{15}$

The unity of the church can be realized only by the power of the Holy Spirit sent from the Father through the Son at Pentecost who preserves in truth all disciples of Christ (cf. John 14:16-17, 25-26), helps

12 Idem, Be Renewed in the Spirit: the Spiritual Roots of Ecumenism, 12.

13 Ibidem, 18-20.

14 Ibidem, 22.

15 St. Cyprian. Treatise IV, On the Lord's Prayer. No. 8; www.ccel.org/ccel/ schaff/ anf05.iv.v.iv.html (Accessed March 15, 2010) as cited in: JWG, Be Renewed in the Spirit: the Spiritual Roots of Ecumenism, 22. 
in human weakness (cf. Rom. 8: 26-27), enables them to call Jesus as Lord (cf. 1 Cor 12:3), and accompanies the church in the historical pilgrimage. The JWG reminds of words from the Canberra statement (1991), that the Holy Spirit "comforts us in pain, disturbs us when we are satisfied to remain in our division, leads us to repentance and grants us joy when our communion flourishes". ${ }^{16}$

Humanity will achieve the fullness of unity only at the end of times, during the second coming of Christ. ${ }^{17}$ The unity that Jesus prays to the Father for will remain a perfect goal Christians need move towards so that "the world will believe" (cf. John 17:20) until all the nations will be gathered in the universal communion with God in Christ. ${ }^{18}$

\section{The Unity of the Church as Koinonia}

The JWG describes the issue of the unity of the Church using the word koinonia. This is to clarify the idea of a specific context of this term meant in the early Christianity. According to their statement, koinonia (from Greek koinos - common, often translated in Latin as communio or communicatio) refers to the nature of the church understood as "people of God', "body of Christ", "temple of the Holy Spirit" and to the multiplicity of local churches belonging to the one universal church. $^{19}$

In the New Testament the term koinonia is mentioned 19 times. It means participation in God's life through Christ in the Holy Spirit (cf. 2 Cor. 13:14), personal relation between God and people (cf. Acts 2:42; John 1:3), partaking in the sufferings of Christ (2 Cor. 1:7; Phil. 3:10) but also in his divine nature (2 Pet. 1:4), sharing of goods among the poor (Rom. 15:26; 2 Cor. 9:13), etc. ${ }^{20}$

The JWG affirms that the community of Christians can be called koinonia as the result of its union with the Triune God through word and sacrament. The vertical character of the communion between believers and God enables people to participate in horizontal unity, that is among themselves. The full koinonia will be realized only in ultimate union with God in his glory. ${ }^{21}$

\footnotetext{
$16 \quad$ Ibidem, 23.

17 Ibidem, 18.

18 Idem, Catholicity and Apostolicity, 2.

19 Idem, The Church: Local and Universal, 5.

20 Ibidem, 6 .

$21 \quad$ Ibidem, 7.
} 
The JWG recalls different statements just mentioned in other dialogical agreements about the koinonia: it "expresses the mystery underlying the various New Testament images of the church" (the Final Report of the Anglican-Roman Catholic International Commission); ${ }^{22}$ church is "a communion subsisting in a network of local churches" (the Lutheran-Roman Catholic Commission), ${ }^{23}$ koinonia "includes participation in God through Christ in the Spirit by which believers become adopted children of the same Father and members of the one body of Christ sharing in the same Spirit" (the Nairobi Report of the Joint Commission between the Roman Catholic Church and the World Methodist Council). ${ }^{24}$

The JWG deals with the issue of the local and universal communion

Theology of dialogue from an ecumenical perspective. The commission agrees that both the local and universal church manifests the one holy catholic and apostolic church confessed by early Christian creeds. ${ }^{25}$

The local church is a community of baptized believers, in which "the word of God is preached, the apostolic faith confessed, the sacraments are celebrated, the redemptive work of Christ for the world is witnessed to, and a ministry of episcopacy exercised by bishops or other ministers is serving". ${ }^{26}$ The problem that exists among Christian churches concerns the place and the role of the bishop in the local church. For churches with the "Catholic" tradition of apostolic succession like the Roman Catholic, Orthodox or Anglican Churches, the local church exists around the bishop, where the Eucharist is celebrated, and usually belongs to the diocese. For Protestant traditions, the local church is identified with the local parish or congregation. ${ }^{27}$

The universal church is the communion of the local churches which are united in faith, proclaiming the word and celebrating the sacraments, presenting together the same church of God. Every local church

22 The Final Report, in: Harding Meyer and Lukas Vischer (eds.), Growth in Agreement: Reports and Agreed Statements of Ecumenical Conversations on a World Level (New York, Paulist Press, and Geneva, WCC, 1984), 65 as cited in: JWG, The Church: Local and Universal, 10.

Facing Unity, 9 as cited in: JWG, The Church: Local and Universal, 10.

Towards a Statement on the Church: Report of the Joint Commission Between the Roman Catholic Church and the World Methodist Council, 1982-1986. Fourth Series. SPCU Information Service 62 (1986), 209 as cited in: JWG, The Church: Local and Universal, 10.

JWG, The Church: Local and Universal, 12.

Ibidem, 15.

Ibidem, 15-17. 
enriches the universal church by cultural, social, and liturgical diversity, participating in the one koinonia. The universality of the church has an ecclesiological, but not organizational dimension, so it doesn't mean the sum of the local churches all over the world. The Roman Catholic and the Orthodox Church represent in their understanding the universal church, while Reformation and Free Churches have developed their universal character through membership in national or regional organizations. ${ }^{28}$

The JWG also presents the different interpretation of ecclesial communion by the RCC and the WCC. According to the Second Vatican Council, the unique church "subsists" in the Catholic Church, but "many elements of sanctification and of truth can be found outside her visible structure", ${ }^{29}$ such as: "the written word of God"; "faith in Christ and in the Trinity"; "baptism"; "the sacraments"; "the life of Theology of dialogue grace"; "faith, hope and charity"; "the interior gifts of the Holy Spirit"; and "prayer and other spiritual benefits". ${ }^{30}$ The document of the JWG affirms that between the RCC and the non-Catholic communities exists "incomplete", but growing communion. ${ }^{31}$ On the other side, the WCC underlines ecclesial elements which were formulated in the two statements of the New Delhi (1961) and Nairobi (1975) assemblies: "the common confession of the apostolic faith", "mutual recognition of the apostolicity and catholicity of the other churches and of each other's members, sacraments and ministries"; "fellowship in the Eucharist, in spiritual life and in mission and service in the world"; and "the achievement of mutual fellowship, also in conciliar meetings and decisions". ${ }^{32}$

The RCC and the WCC acknowledge that the ecclesial elements mentioned above in different ways are present in their traditions. The problem of full communion remains in those churches which don't recognize Eucharistic fellowship among themselves. At the same time the JWG agrees that nowadays it is possible to speak about existing recognition of imperfect communion which is the result of ecumenical efforts among the churches through their mutual understanding, respect, common prayers, theological dialogue and service to humanity.

Ibidem, 19-20.

Lumen Gentium, 8 as cited in: JWG, The Church: Local and Universal, 26.

Unitatis redintegratio 3, 20-23 as cited in: JWG, The Church: Local and Universal, 26.

JWG, The Church: Local and Universal, 26.

Ibidem, 28-31. 
Theology of dialogue

The main commitment for the churches is to restore that koinonia present in Christian communities before the division..$^{33}$

The JWG describes issues of the canonical structures in the church, which allow for different local churches to coexist in communion, harmony and fidelity to the faith. In the RCC every bishop can carry out his ministry only in communion with the Bishop of Rome and the college of bishops. Orthodox bishops have to be in communion with the head of the synod. Protestant churches have developed presbyteries and synodical structures to ensure the communion in their churches and provide the expression of their common faith, cooperation and witness on the universal level. According to the teaching of the RCC, the Pope as the successor of Peter is a sign and guarantee of ecclesial communion among the churches and their communion with Rome. The JWG underlines that until nowadays the problem of the primacy of jurisdiction, infallibility and the papal teaching authority remains an ecumenical problem for non-Catholic churches. ${ }^{34}$

\section{Unity in the Life and Worship of the Church}

According to the JWG teaching, the community of believers takes its origin from Pentecost, when the Holy Spirit promised by the Lord was sent on the apostles. This is understood as the beginning of the church (cf. Acts 1:8). The unity of the church can be rediscovered in its communion with God. The prayer for unity is a continuation of Jesus' prayer that "all may be one" (John 17:21) and is considered as the soul of the ecumenical movement. ${ }^{35}$

In spite of the separations still dividing the churches, Christians can grow in a spiritual fellowship. ${ }^{36}$ First of all, they are incorporated into the Church, the body of Christ, through the sacrament of baptism, which is fundamental for Christian life. ${ }^{37}$ Baptism involves Christians turning away from sin and experiencing the new life in Christ and the

\footnotetext{
$33 \quad$ Ibidem, 32-34, 38 .

$34 \quad$ Ibidem, $42-47$.

35 Idem, Be Renewed in the Spirit: the Spiritual Roots of Ecumenism, 29, 30, 42.

36 Idem, "Joint Worship at Ecumenical Gatherings" (report), 1, in: Joint Working Group between the Roman Catholic Church and the World Council of Churches. First Official Report, in: Information Service 1 (1967), 18-24.

37 Idem, "Ecclesiological and Ecumenical Implications of a Common Baptism" (study document"), 67 and 111, in: Joint Working Group Between The Roman Catholic Church and the World Council of Churches, Eighth Report 1999-2005, (Geneva-Rome: WCC Publications Geneva, 2005), 45-72.
} 
Holy Spirit. ${ }^{38}$ All Christians are called to repentance and conversion that is understood by the JWG as a basis for unity. ${ }^{39}$

Some churches celebrate the three sacraments of Christian initiation in a way which shows that they belong closely together: baptism, confirmation and Eucharist, while for others baptism alone is satisfactory to become a member of the church. Still another point represents churches which understand baptism as a profession of faith in Jesus Christ. The JWG recognizes the need to develop a common approach of the churches on the sacraments, their relation to the church, and the mission of the church. ${ }^{40}$ An important step towards a common understanding of sacraments was made by the convergent document on Baptism, Eucharist and Ministry (1982), which was appreciated by the JWG and gives new opportunities for worshipping ecumenically. ${ }^{41}$ The convergences which have been achieved are very important steps in the ecumenical movement, but also further activities should be taken. ${ }^{42}$

Christian churches pray for one another in a variety of ways. The JWG between the RCC and the WCC underlines also the necessity to pray with each other. Prayer takes a central place in Christian identity. Christians coming from different churches through praising God and asking for unity in the church become a visible sign of ecumenical progress already achieved. Various communities in the world, such as the Chemin Neuf Community, the Focolare Movement, the Community of Grandchamp, the Iona Community, the Ecumenical Community of Taizé, the Monastic Community of Bose, and others are examples of sharing this ecumenical spirituality in their common life..$^{43}$

The Lord's Prayer used in private and public worship can be a strong sign of the unity which is shared among Christians from their baptism and is advised to be practiced during common ecumenical worship. Churches can influence each other by sharing their experience of worship through hymns, canticles, music from the Taizé community, charismatic and Pentecostal styles of worship, especially regarding spiritual songs, Psalms prayer, etc. ${ }^{44}$ Christian unity doesn't mean

$38 \quad$ Ibidem, 84 .

39 Idem, Be Renewed in the Spirit: the Spiritual Roots of Ecumenism, 25.

40 Idem, Ecclesiological and Ecumenical Implications of a Common Baptism, 68 and 82 .

41 Idem, Be Renewed in the Spirit: the Spiritual Roots of Ecumenism, 52.

42 Idem, Ecclesiological and Ecumenical Implications of a Common Baptism, 112.

43 Idem, Be Renewed in the Spirit: the Spiritual Roots of Ecumenism, 44-46, 49.

44 Ibidem, 50-51. 
uniformity, but gives an enriching opportunity of spiritual and cultural diversity among the churches. ${ }^{45}$

The JWG recommends to the RCC and the WCC several practical ecumenical initiatives on their way to unity: the Week of Prayer for Christian Unity, promoting of the Ecumenical Prayer cycle, common Bible studies, regular prayer for unity during a worship service, fasting, ecumenical hospitality, pilgrimages, common support of justice, peace and creation, ecumenical education, etc. ${ }^{46}$

\section{Common Witness of the Churches}

Theology of dialogue

The JWG between the RCC and the WCC underlines that the missionary character of the church obliges her to proclaim God's salva-

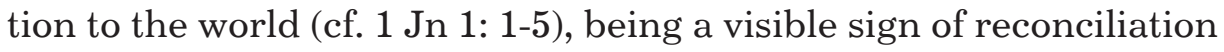
and love. ${ }^{47}$ Christ called his disciples to be His witnesses to "the ends of the earth" (Acts 1:8) and he assured them of his constant presence (cf. Mt 28, 20), but for centuries due to divisions Christians have not been a clear sign of the mandate they have received. ${ }^{48}$ The mission of the church is directly related to the ecumenical movement, because the existing divisions contradict the unity in Christ (cf. Jn 17:21). ${ }^{49}$ A common witness of the churches will be possible only through good will to forgive past offences. ${ }^{50}$ Nowadays Christians try to restore lost communion being aware that indifference, isolation and rivalry are obstacles to God's vision of unity. ${ }^{51}$ Only in growing communion, rooted in the life of the Trinity, is Christian witness strengthened..$^{52}$

In the contemporary globalized world Christians are called to make their contribution to the unity of all humanity, being a seed of hope in economic, cultural, social or political life. ${ }^{53}$ As moral witnesses in

\footnotetext{
$45 \quad$ Ibidem, 12.

46 Ibidem, 77.

47 Idem, "The Challenge of Proselytism and the Calling to Common Witness" (study document), 7-8, in: Information Service 91 (1996/I-II), 77-83.

48 Idem, "Common Witness and Proselytism" (study document), 1, in: Information Service 14 (1971/II), 13-23.

49 Idem, The Challenge of Proselytism and the Calling to Common Witness, 9.

50 Idem, Common Witness and Proselytism, 21.

$51 \quad$ Ibidem, 2 and 9.

52 Idem, The Church: Local and Universal, 8.

53 Idem, The Nature and Purpose of Ecumenical Dialogue, 83-84.
} 
a pluralistic society they need to seek ways of dialogue and collaboration with other communities and people of good will. ${ }^{54}$

The JWG acknowledges the right of religious freedom, also in Christian witness, of every human person and rejects all forms of religious violation and intolerance in the world. Churches are encouraged to promote these principles and apply them in practice through dialogue and mutual respect, contributing to harmony and peace in society. ${ }^{55}$ The JWG mentions the following qualities required for Christian witness: a commandment of love (cf. Mt. 22:37 and 39); true inspiration by the glory of God; the conviction of the Holy Spirit's action through his grace and light; respect of humans' free will and dignity; lack of physical and moral coercion or psychological pressure.$^{56}$ Common witness should take place in different social areas: development of the whole humanity; human rights, religious freedom and peace in the world; struggle with economic, social and racial injustice; eradication of illiteracy, hunger, alcoholism, prostitution, the traffic in drugs; medical care, helping victims of natural disasters, etc. ${ }^{57}$

\section{Conclusion}

After analyzing the dialogue documents of the JWG between the RCC and the WCC dealing with the issue of unity of the church, it becomes clear that the internal principle of ecclesial communion is the Trinity, which shows the relationship of mutual love between the three divine persons of the Father, the Son and the Holy Spirit as a gift and a task for the community of believers. The unity of the church is rooted in the Scriptures. In particular, the dialogue committee of the JWG emphasizes the high-priestly prayer of Christ and the Lord's Prayer, contained in the Gospel, as the basis for the unity of ecclesiological communion. Early Christian koinonia is an example of unity for which the churches should strive. Although today it is possible to talk about the existence of an incomplete communion between Christians, it is necessary to look with hope to the future, when all faithful gather together for the Eucharist, the foretaste of the heavenly communion.

Idem, "The Ecumenical Dialogue on Moral Issues: Potential Sources of Common Witness or of Divisions" (study document), VI.1, in: Information Service 91 (1996/I-II), 83-90.

Idem, The Challenge of Proselytism and the Calling to Common Witness, 15-17.

Idem, Common Witness and Proselytism, 26b-27.

Ibidem, 14 . 
Despite the lack of total unity Christians, incorporated into the church through the sacrament of baptism, already can grow in spiritual community through common prayer and daily life, becoming a visible sign of achieved progress in the ecumenical movement. And finally, they are called to overcome existing divisions between them, in order to be credible witnesses to the unity of the church in the world, to which they are sent by Christ himself to preach the Good News in a spirit of reconciliation and love.

\section{JEDNOŚĆ KOŚCIOŁA W DIALOGU EKUMENICZNYM POMIĘDZY KOŚCIOŁEM RZYMSKOKATOLICKIM I ŚWIATOWĄ RADĄ KOŚCIOŁÓW}

Jedność Kościoła pozostaje priorytetowym zadaniem dla podzielonych chrześcijan. Wewnętrzną zasadę każdej eklezjalnej komunii stanowi Trójca Święta. Relacja wzajemnej miłości Ojca, Syna i Ducha Świętego jest darem i zadaniem dla wspólnoty wierzących. Jedność Kościoła jest zakorzeniona w Piśmie Świętym. Komisja dialogowa w sposób szczególny akcentuje modlitwę arcykapłańską Chrystusa oraz modlitwę Pańską jako bazę biblijną dla działalności ekumenicznej Kościoła. Wczesnochrześcijańska koinonia jest przykładem jedności, ku której podzieleni chrześcijanie powinni dążyć. Pomimo braku pełnej komunii Kościoły i Wspólnoty chrześcijańskie już dzisiaj mogą wzrastać w duchowej jedności poprzez modlitwę i codzienne życie, stając się świadkami pojednania i miłości w podzielonym świecie.

Słowa kluczowe: Jedność, Kościół, Wspólna Grupa Robocza, Kościół rzymskokatolicki, Światowa Rada Kościołów .

\section{Bibliography:}

\section{Documents of the JWG}

1. "Joint Worship at Ecumenical Gatherings" (report). In: Joint Working Group between the Roman Catholic Church and the World Council of Churches. First Official Report. In: Information Service 1 (1967), 18-24.

2. "Catholicity and Apostolicity" (study document). In: Joint Working Group between the Roman Catholic Church and the World Council of Churches. Third Official Report. In: One In Christ 4, 3 (1970), 452-483 and Ecumenical Review 23, 1 (1971), 51-69.

3. "Common Witness and Proselytism" (study document). In: Information Service 14 (1971/II), 13-23. 
4. "The Church: Local and Universal" (study document). In: Joint Working Group between the Roman Catholic Church and the World Council of Churches. Sixth Report. Geneva-Rome: WCC Publications, 1990, 23-37.

5. "The Challenge of Proselytism and the Calling to Common Witness" (study document). In: Information Service 91 (1996/I-II), 77-83.

6. "The Ecumenical Dialogue on Moral Issues: Potential Sources of Common Witness or of Divisions" (study document). In: Information Service 91 (1996/I-II), 83-90.

7. "Ecclesiological and Ecumenical Implications of a Common Baptism" (study document"). In: Joint Working Group Between The Roman Catholic Church and the World Council of Churches. Eighth Report 1999-2005. Geneva-Rome: WCC Publications, 2005, 45-72.

8. "The Nature And Purpose Of Ecumenical Dialogue" (study document). In: Joint Working Group between The Roman Catholic Church and the World Council of Churches. Eighth Report 1999-2005. Geneva-Rome: WCC Publications Geneva, 2005, 73-89.

9. "Be Renewed in the Spirit: the Spiritual Roots of Ecumenism". In: Joint Working Group between the Roman Catholic Church and the World Council of Churches. Ninth Report 2007-2012. Geneva: WCC Publications, 2013, 103-138. 